The Journal of Toxicological Sciences, Vol. 17, 81-90, 1992

\title{
BEHAVIORAL EVALUATION OF PSYCHO- PHARMACOLOGICAL AND PSYCHOTOXIC ACTIONS OF METHYLXANTHINES BY AMBULATORY ACTIVITY AND DISCRETE AVOIDANCE IN MICE
}

\author{
Hisashi KURIBARA, Toshio ASAHI ${ }^{*}$ and Sakutaro TADOKORO \\ Division for Behavior Analysis, Behavior Research Institute, \\ Gunma University School of Medicine, 3-39-22 Showa-machi, Maebashi 371, Japan \\ *Pharmacological Research Laboratory, Tanabe Seiyaku Co., Ltd., \\ 2-2-50 Kawagishi, Toda 335, Japan
}

Accepted March 30, 1992

\begin{abstract}
The behavioral effects of methylxanthines, caffeine, theophylline and theobromine, were compared by means of ambulatory activity and discrete lever-press avoidance response in mice. The single oral administration of $10-100 \mathrm{mg} / \mathrm{kg}$ of caffeine, $30-300 \mathrm{mg} / \mathrm{kg}$ of theophylline, and $10 \mathrm{mg} / \mathrm{kg}$ of theobromine singnificantly increased the mouse's ambulatory activity. However, $1000 \mathrm{mg} / \mathrm{kg}$ of theobromine decreased the activity. The ambulation-increasing effect of methamphetamine $(2 \mathrm{mg} / \mathrm{kg}$ s.c.) was enhanced by coadministration with caffeine $(3-100 \mathrm{mg} / \mathrm{kg}$ ), theophylline $(10-300 \mathrm{mg} / \mathrm{kg})$, and theobromine $(10-100 \mathrm{mg} / \mathrm{kg})$. On the other hand, comparatively higher doses of caffeine (up to $30 \mathrm{mg} / \mathrm{kg}$ ) slightly but significantly decreased the avoidance rate without eliciting any significant change in the response rate. Theobromine significantly decreased the response rate at higher than $300 \mathrm{mg} / \mathrm{kg}$, and the avoidance rate at higher than $100 \mathrm{mg} / \mathrm{kg}$. Furthermore, $1000 \mathrm{mg} / \mathrm{kg}$ of theobromine was much toxic for mice, i.e., half mice died within a few hr after the end of the 1-hr avoidance session. Theophylline did not produce any significant change in the avoidance response at the dose range of $3-300 \mathrm{mg} / \mathrm{kg}$. These results may indicate the relative order of the centrally stimulant and/or behavioral toxic actions of methylxanthines in human.
\end{abstract}

Key words: Methylxanthines, mouse's ambulation, discrete lever-press avoidance, methamphetamine-interaction, central action.

Correspondence : Hisashi KURIBARA at the above address. 


\section{INTRODUCTION}

On a psychopharmacological view point, there are 3 important natural methylxanthines, caffeine, theophylline and theobromine. These methylxanthines possess centrally stimulant action through adenosine antagonism (Fredholm, 1980; Cardinali, 1980 ; Snyder et al., 1981 ; Daly et al., 1983 ; Marongos, 1985 ; Staahle et al., 1990), inhibition of phosphodiesterase (Butcher and Sutherland, 1962), calcium blockade (Hagiwara and Buerly, 1981), catecholamine release (Bellet et al., 1969; Berkowitz et al., 1970), and direct action on dopamine receptor (Lundberg et al., 1981 ; Watanabe et al., 1981 ; Fredholm et al., 1983 ; Herrera-Marschitz et al., 1988 ; Casas et al., 1989).

The pharmacological and toxicological actions of caffeine have been attended on the clinical and experimental basis. Because the central actions of methylxanthines are empirically considered to be strong in order of caffeine, theophylline and theobromine. Some behavioral and neurochemical reports also partially confirmed such order (Dews, 1982; Katims et al., 1983 ; Carney, 1984; McKim, 1986). However, there is a surprising lack of information about the characteristics of behavioral effects of methylxanthines on the same experimental basis (Carney, 1984).

Although the centrally stimulant actions of methylxanthines are much weaker than those of typical central stimulants such as methamphetamine and cocaine, it should be attended to the fact that large amounts of methylxanthines, particularly caffeine and theobromine, have been consumed not only by adult but also by children in our every day life through taking foodstuffs and beverages. For examples, a cup of regular coffee or tea contains $50-100 \mathrm{mg}$ of caffeine, and about 500 $\mathrm{mg}$ and $150-300 \mathrm{mg}$ of theobromine is contained in 50-g chocolate bar and a cup of hot chocolate, respectively (McKim, 1986).

Furthermore, caffeine is one of popular drugs which are added in street-selling stimulants such as amphetamines and cocaine, probably for enhancing their actions (Misra et al., 1986 ; Logan et al., 1989). However, methylxanthines have been reported to enhance the toxicity of amphetamines and their analogies (Pentel, 1984 ; Schlemmer et al., 1984). In these respects, we were interested in determining the pharmacological and toxicological effects of methylxanthines, and the interaction with methamphetamine.

Hence, the purposes of this investigation were to assess the behavioral effects of 3 methylxanthines by ambulatory activity and discrete lever-press avoidance in mice. The ambulatory activity is a typical unconditioned behavior, and it is convenient for evaluation of the behavioral stimulant effect of drugs. The discrete avoidance is a conditioned behavior, and it can easily detect the behavioral disruption induced by drugs. 
Behavioral effects of methylxanthines

\section{MATERIALS AND METHODS}

Animals :

The experimental animals were male mice of the dd strain (Breeding Colony of Gunma University School of Medicine) and ddY strain (Japan Laboratory Animals). According to our experience, these two strains of mice showed similar behavioral characteristics and responses to drugs. They were used at 7 weeks of age weighed 25-30 g. The former and the latter strains of mice were subjected for ambulation measurment and avoidance experiment, respectively. Prior to the start of and during the experiment, they had been group-housed in standard breeding cages (10 mice/cage) with a free access to solid diet (MF, Oriental Yeast) and tap water. The breeding room was controlled so that the light-dark schedule (light period; 06:00-18:00) and temperature $\left(23 \pm 1^{\circ} \mathrm{C}\right)$ were almost constant.

\section{Drugs :}

Drugs used were caffeine, theophylline and theobromine (Kanto Chemical), and methamphetamine $\mathrm{HCl}$ (Dainippon Pharm.). These drugs were dissolved and/or suspended in physiological saline, and the concentration of each drug solution or suspension was adjusted so that each volume administered was constant at $0.1 \mathrm{ml} / 10$ g body weight.

Ambulation measurement:

The ambulatory activity in mice was measured using a tilting-type ambulometer (AMB-10, O'Hara \& Co.). Mice were individually put into Plexiglas activity cages with a diameter of $20 \mathrm{~cm}$, and their ambulatory activities were measured for $30 \mathrm{~min}$ and $3 \mathrm{hr}$ before and after the drug administration, respectively.

In this experiment, effects of the single oral administration of caffeine $(1,3,10$, 30 and $100 \mathrm{mg} / \mathrm{kg}$ ), theophylline $(3,10,30,100$ and $300 \mathrm{mg} / \mathrm{kg})$ and theobromine $(3$, $10,30,100,300$ and $1000 \mathrm{mg} / \mathrm{kg}$ ), as well as coadministration with methamphetamine ( $2 \mathrm{mg} / \mathrm{kg}$ s.c.) were evaluated. The dose of methamphetamine was considered to be optimum for increasing ambulatory activity in the dd strain mice (Kuribara and Tadokoro, 1989). The administration of physiological saline alone (p.o. plus s.c.), and coadministration of physiological saline (p.o.) with methamphetamine (s.c.) were held as the control for individual experiments.

In each drug testing, 10-20 drug-naive mice were used. The ambulation measurment was carried out between 9:00-16:00.

\section{Avoidance experiments :}

The lever-press avoidance experiment was conducted using experimental chamber, behavior-controlling and data-recording units (GT-8450, De CARES GT-M5 and TIDP-10, respectively; O'Hara \& Co.). The temporal parameters of discrete avoidance schedule were an intertrial interval of $22 \mathrm{sec}$, and a warning duration of $5 \mathrm{sec}$. An electric foot shock of $100 \mathrm{~V}, 0.3 \mathrm{~mA}, 50 \mathrm{~Hz}$ AC was delivered through the floor grid of the chamber as the unconditioned stimulus for the maximum duration of $3 \mathrm{sec}$, but an escape response could stop the shock. Each 


\section{H. KURIBARA et al.}

session consisted of 60 min performance in which 120 avoidance trials were carried out at intervals of $30 \mathrm{sec}$. The indices of the avoidance response were the response rate (frequency of lever-presses) and the avoidance rate (number of avoidance responses/number of avoidance trials.).

In this avoidance experiment, well trained 10 mice were used repeatedly, and effects of single oral administration of caffeine $(1,3,10,30$ and $100 \mathrm{mg} / \mathrm{kg}$ ), theophylline $(3,10,30,100$ and $300 \mathrm{mg} / \mathrm{kg})$ and theobromine $(3,10,30,100,300$ and $1000 \mathrm{mg} / \mathrm{kg}$ ) were evaluated. The drug was administered immediately before start of the $1 \mathrm{hr}$-session, and such drug testing sessions were repeated at intervals of 3-4 days. On the days before the drug administration, physiological saline was administered as the control. The doses administered were changed from lower to the higher.

All avoidance experiments were held between 9:00-16:00.

\section{Statistical analysis :}

The mean overall ambulatory activity counts for $3 \mathrm{hr}$ after the drug administration, and mean response and avoidance rates were calculated in individual groups of mice. These data were first analyzed by ANOVA. If there were significant overall effects, comparisons between individual date were carried out by the two-tailed t-test and/or the Cochran-Cox test. When $\mathrm{P}$ values were equal to and/or less than 0.05 , they were defined to be significant difference.

\section{RESULTS}

\section{Ambulation measurement :}

As shown in Fig. 1, the single administration of $10-100 \mathrm{mg} / \mathrm{kg}$ of caffeine,

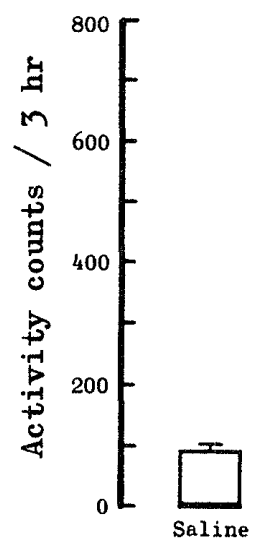

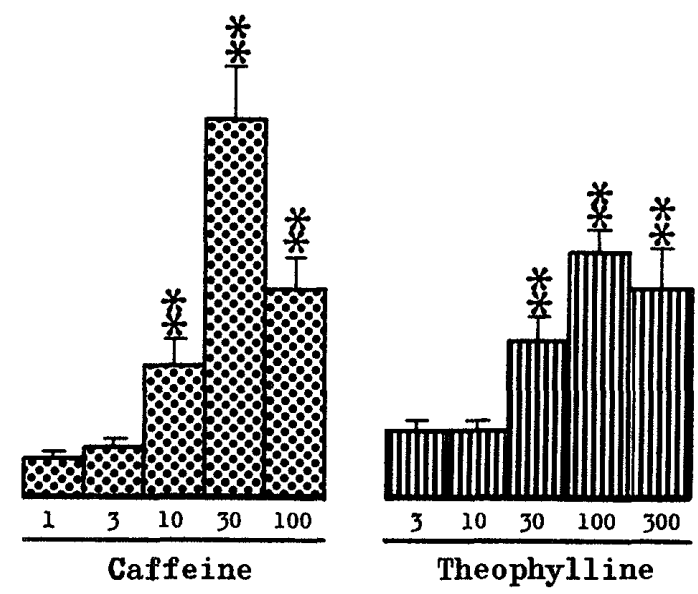

Theophylline

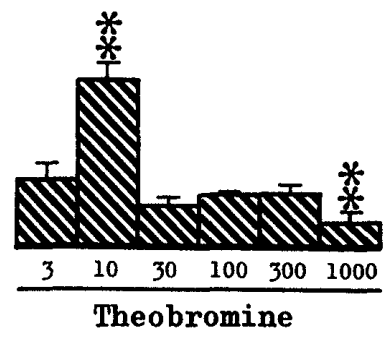

Theobromine

Fig. 1. The mean 3-hr overall activity counts with SEMs after the oral administration of caffeine $(1,3,10,30$ and $100 \mathrm{mg} / \mathrm{kg})$, theophylline $(3,10,30,100$ and $300 \mathrm{mg} / \mathrm{kg})$ and theobromine $(3,10,30,100,300$ and $1000 \mathrm{mg} / \mathrm{kg})$ in mice. *and**: Significantly different from the saline-administered control value $(P<0.05$ and 0.01 , respectively). $\mathrm{N}=10-20$ 
$30-300 \mathrm{mg} / \mathrm{kg}$ of theophylline, and $10 \mathrm{mg} / \mathrm{kg}$ of theobromine significantly increased ambulatory activity in mice. The maximum activity counts produced were about 600,400 and 280 counts by caffeine $(30 \mathrm{mg} / \mathrm{kg})$, theophylline $(100 \mathrm{mg} / \mathrm{kg})$ and theobromine $(10 \mathrm{mg} / \mathrm{kg})$, respectively. In contrast, $1000 \mathrm{mg} / \mathrm{kg}$ of theobromine significantly decreased the activity. A gross observation revealed that, at $300-1000$ $\mathrm{mg} / \mathrm{kg}$ of theobromine, some mice exhibited convulsion, and at $1000 \mathrm{mg} / \mathrm{kg}, 3$ out of 10 mice died $4-6 \mathrm{hr}$ after the administration.

As shown in Fig. 2, methamphetamine $(2 \mathrm{mg} / \mathrm{kg})$ significantly increased the mouse's ambulatory activity, and the count was much higher than those after the single administration of methylxanthines. Caffeine $(3-100 \mathrm{mg} / \mathrm{kg})$, theophylline $(10-300 \mathrm{mg} / \mathrm{kg})$, and theobromine $(10-100 \mathrm{mg} / \mathrm{kg})$ significantly enhanced the ambulation-increasing effect of methamphetamine.

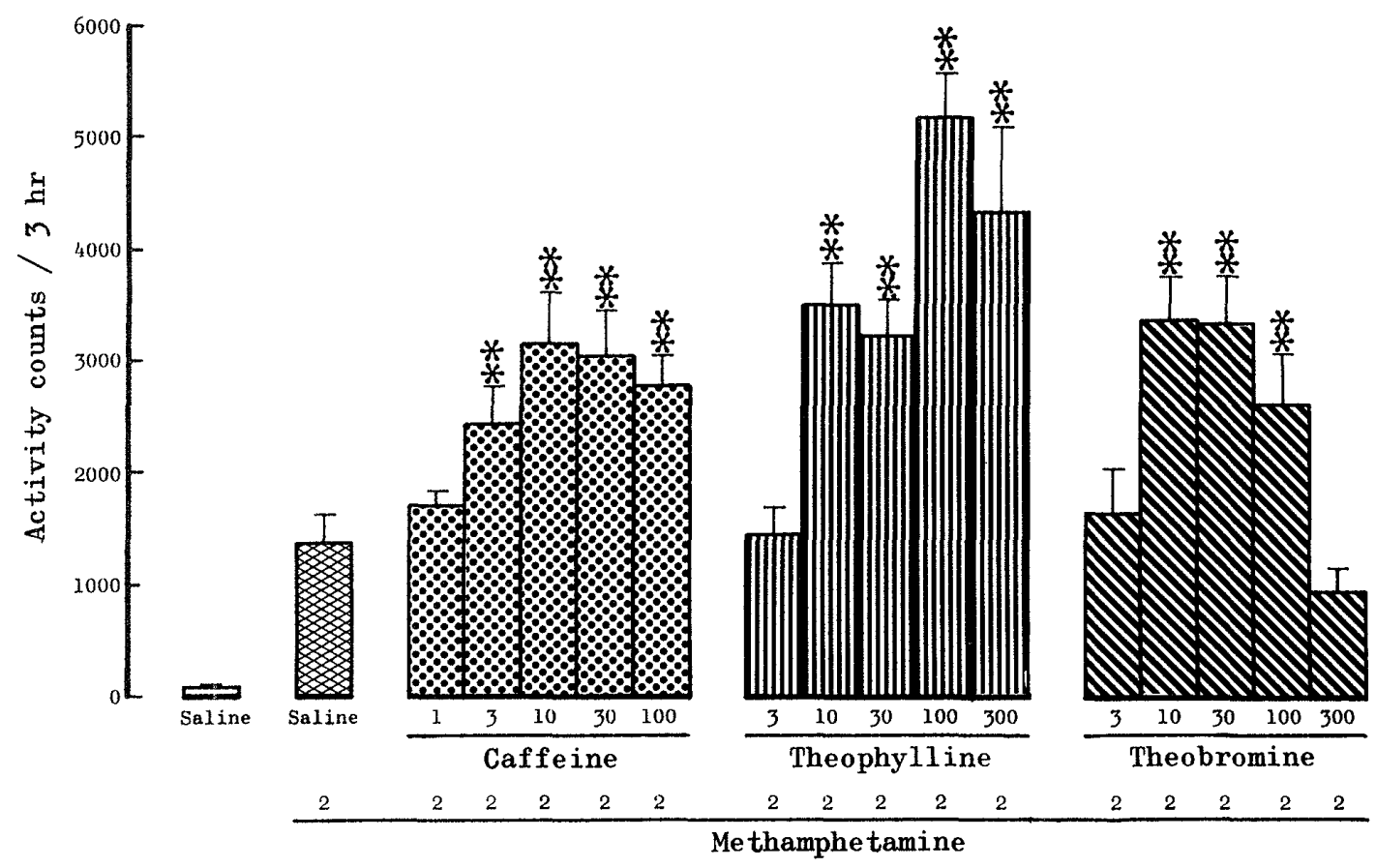

Fig. 2. The mean 3-hr overall activity counts with SEMs after the coadministration of caffeine $(1,3,10,30$ and $100 \mathrm{mg} / \mathrm{kg}$ p.o.), theophylline $(3,10,30,100$ and $300 \mathrm{mg} / \mathrm{kg}$ p.o.) and theobromine $(3,10,30,100$ and $300 \mathrm{mg} / \mathrm{kg}$ p.o.) with methamphetamine $(2 \mathrm{mg} / \mathrm{kg} \mathrm{s.c.})$ in mice. The two drugs were administered at the same time. *and**: Significantly different from the methamphetamine + saline-administered control value $(\mathrm{P}<0.05$ and 0.01 , respectively). $\mathrm{N}=10-20$.

\section{Avoidance experiment :}

As shown in Fig. 3, 30 and $100 \mathrm{mg} / \mathrm{kg}$ of caffeine slightly but significantly decreased the avoidance rate without eliciting any significant change in the response rate. Theophylline was without effect for producing a significant change in the response and avoidance rates at the dose range of $3-300 \mathrm{mg} / \mathrm{kg}$. Theobromine significantly decreased the response rate at doses of over $300 \mathrm{mg} / \mathrm{kg}$, and avoidance 

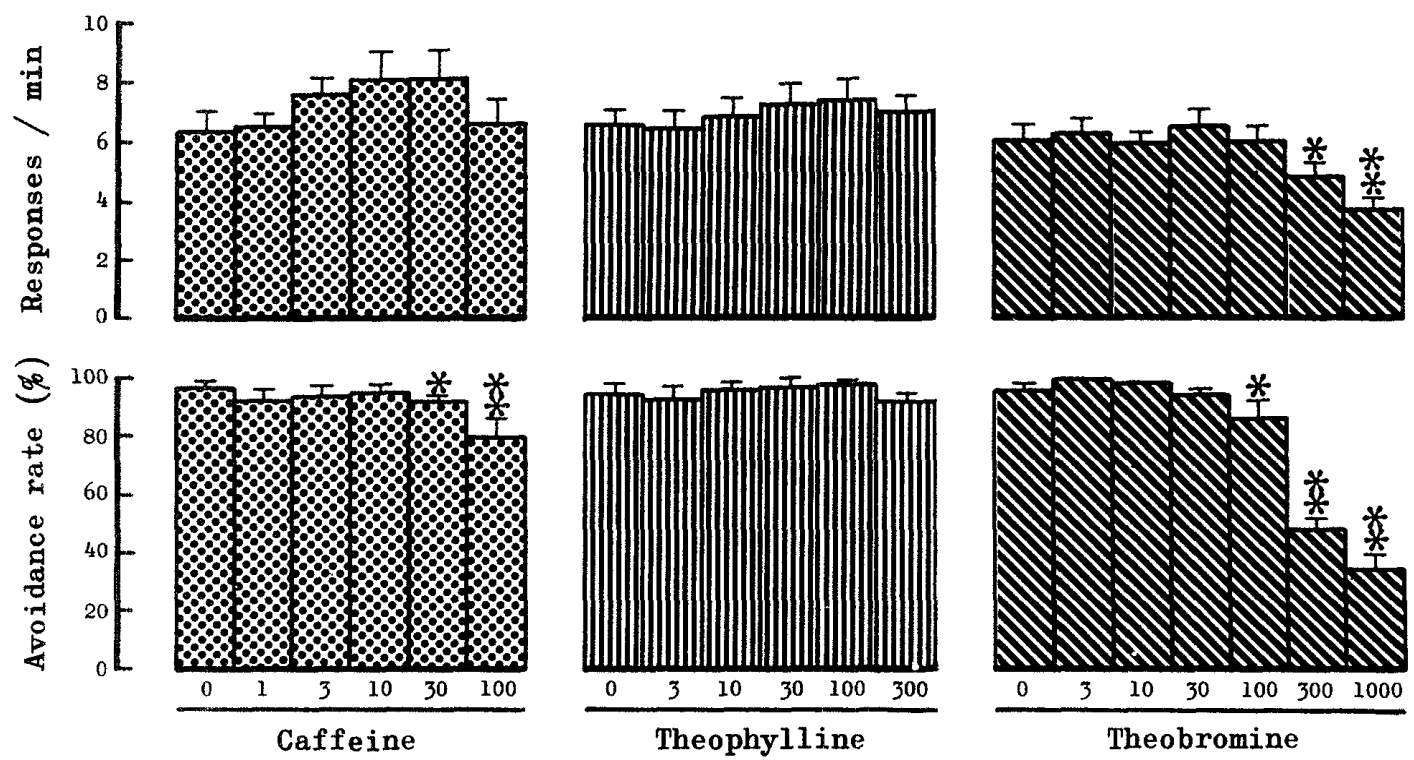

Fig. 3. Effects of single oral administration of caffeine (1, 3, 10, 30 and $100 \mathrm{mg} / \mathrm{kg})$, theophylline $(3,10,30,100$ and $300 \mathrm{mg} / \mathrm{kg})$ and theobromine $(3,10,30,100,300$ and $1000 \mathrm{mg} / \mathrm{kg}$ ) on discrete lever-press avoidance in mice. The mean overall response rate (frequency of lever-presses : upper panel) and avoidance rate (lower panel) in the 1-hr session are presented with the SEMs. *and**: Significantly different from the saline-administered $($ dose $=0)$ control value $(P<0.05$ and 0.01 , respectively). $N=10$.

rate at over $100 \mathrm{mg} / \mathrm{kg}$. Five out of 10 mice given $1000 \mathrm{mg} / \mathrm{kg}$ of theobromine died within a few hr after the end of the 1 -hr avoidance session.

\section{DISCUSSION}

The present experiment confirmed the empirical concept that the central actions of methylxanthines are strong in order of caffeine, theophylline and theobromine. However, the maximum activity counts of approximately 600, 400 and 280 counts after aministration of caffeine $(30 \mathrm{mg} / \mathrm{kg})$, theophylline $(100 \mathrm{mg} / \mathrm{kg})$ and theobromine $(10 \mathrm{mg} / \mathrm{kg})$, respectively, were much smaller than about 1300 count after the administration of methamphetamine. These results clearly indicate that the methylxanthines have weaker action than methamphetamine in terms of the centrally stimulant effect. Furthermore, the higher doses of these drugs were less potent than the intermediate doses in the ambulation-increasing effect, and inverted U-shape pattens for the dose-effect relationships were observed. Such dose-effect relationships have been also reported by many researchers (Holtzman et al., 1983 ; Seale et al., 1984 ; Carney et al., 1985 ; Fujii et al., 1989) after the administration of caffeine and/or theophylline. The less potency of the ambulation-increasing effect at the higher doses might reflect the development of the toxic action of methylxanthines. This consideration can be also supported by the fact that, after the administration of up to $300 \mathrm{mg} / \mathrm{kg}$ of theobromine, some mice demonstrated 
convulsion, and half mice died after $1000 \mathrm{mg} / \mathrm{kg}$. Caffeine and theophylline also have convulsive action at high dose (Dews, 1982).

It has been reported that methylxanthines show centrally stimulant action through inhibition of phosphodiesterase (Butcher and Sutherland, 1962), calcium blockade (Hagiwara and Buerly, 1981), adenosine antagonism (Cardinali, 1980; Fredholm, 1980 ; Snyder et al., 1981 ; Daly et al., 1983 ; Marangos, 1985 ; Staahle et al., 1990), catecholamine release (Bellet et al., 1969 ; Berkowitz et al., 1970), and/or direct action on catecholamine receptors (Lundberg et al., 1981; Watanabe et al., 1981 ; Fredholm et al., 1983 ; Herrera-Marschitz et al., 1988 ; Casas et al., 1989). In this experiment, a significant enhancement of the ambulation-increasing effect was produced when caffeine, theophylline and theobromine were coadministered with methamphetamine. The ambulation-increasing effect of methamphetamine is mainly induced through enhancement of release and inhibition of reuptake of catecholamines at the synapse level (McMillen, 1983). The enhancing interaction between methylxanthines and methamphetamine may be produced through an activation of catecholaminergic systems.

It should be noted that the ambulatory activity counts after the coadministration of theophylline with methamphetamine were much higher than those after the coadministration of caffeine with methamphetamine. In the case of theobromine, the activity counts were almost the same with those after the coadministration of caffeine with methamphetamine. These results suggests that, although the centrally stimulant actions of theophylline and theobromine are less potent than that of caffeine, a dramatic enhancement of the centrally stimulant action may be produced after the coadministration of theophylline or theobromine with methamphetamine.

On the other hand, caffeine and theobromine disrupted the avoidance response at comparatively higher doses. The avoidance rate was significantly decreased by up to $30 \mathrm{mg} / \mathrm{kg}$ of caffeine, and up to $100 \mathrm{mg} / \mathrm{kg}$ of theobromine. The dose of caffeine that is effective for disruption of the lever-press avoidance response is almost the same with that reported previously (Kuribara and Tadokoro, 1989). Moreover, theobromine significantly decreased the response rate at higher than $300 \mathrm{mg} / \mathrm{kg}$. In the discrete avoidance task, mice were required to make response during the presentation of warning signal. Thus, it is indicated that, at comparatively higher doses, caffeine and theobromine disrupt discriminative function to the external signal, i.e., development of behavioral toxicity. Whereas, theophylline did not modify the avoidance response, though it significantly increased the ambulatory activity at the dose range of $10-300 \mathrm{mg} / \mathrm{kg}$. This result indicates that theophylline is less toxic than caffeine and theobromine.

We have taken methylxanthines through consumption of foodstuffs and beverages as well as through preparation. There are $50-150 \mathrm{mg}$ and $30-75 \mathrm{mg}$ of caffeine in one cup of coffee and tea, respectively, and 150-500 mg and 150-300 mg of theobromine in one $50 \mathrm{~g}$-chocolate bar and one cup of hot chocolate (McKim, 1986). Theophylline (or its water soluble compound aminophylline) is frequently 


\section{H. KURIBARA et al}

contained in various kind of drug preparations. The centrally stimulant action induced by coffee- and tea-drinking has been well known, and the behavioral disorders induced by heavy coffee-drinking, and abuse of caffeine-containing preparation have been concerned (Dews, 1982; McKim, 1986; Kuribara and Tadokoro, 1989). However, such effects induced by theophylline and theobromine, particularly theobromine, have been scarcely considered. In the present experiment, theobromine increased the ambulatory activity at $10 \mathrm{mg} / \mathrm{kg}$ in mice. We also confirmed the behavioral actions of cocoa powder $(1 \mathrm{~g} / \mathrm{kg})$, and estimated its potency to be almost equivalent with that of theobromine $(10 \mathrm{mg} / \mathrm{kg}$ ) (Kuribara and Tadokoro, 1992). The doses of theobromine and cocoa powder are corresponded to the consumption of one 50 g-chocolate bar and/or 2 cups of hot chocolate. Human has generally much higher sensitivity than animals to the centrally acting drugs. Thus, it is highly probable that we have experienced the central action of theobromine alone, and/or the synergistic interaction with certain central stimulants, through consumption of various kinds of theobromine-containing foodstuffs and beverages even at comparatively smaller amount. Moreover, children are more sensitive to drugs than adults. In these respects, as reported harmful effects induced by heavy coffee drinking (Dews, 1982), the consumption of large amount of cocoa, chocolate, and the other theobromine-containing foodstuffs and/or beverages should be avoided in children, and even in adults.

\section{REFERENCES}

Bellet, S., Roman, L., De Castro, O., et al. (1969) : Effect of coffee ingestion on catecholamine release. Metabolism, 18, 288-291.

Berkowitz, B. A., Tarver, J. H. and Spector, S. (1970): Release of norepinephrine in the central nervous system by theophylline and caffeine. Eur. J. Pharmacol., $10,64-71$.

Butcher, R. W. and Sutherland, E.W. (1962): Adenosine 3', 5'-phosphate in biological materials. J. Biol. Chem., 237, 1244-1250.

Cardinali, D. P. (1980) : Methylxanthines : Possible mechanisms of action in brain. Trends Pharmacol. Sci., 1, 405-407.

Carney, J. M. (1984) : Effect of caffeine, theophylline and theobromine on schedule controlled responding in rats. Br. J. Pharmacol., 75, 451-454.

Carney, J. M., Logan, L., McMaster, S. B., et al. (1985) : Can we understand the CNS pharmacology of xanthines when we understand CNS adenosine systems? In Adenosine: Receptors and Modulation of Cell Function (V. Stephanovich, K. Rudolphi, and P. Schubert, eds.), p. 199-208. IRL Press, Oxford.

Casas, M., Ferre, S., Cadafalch, J., et al. (1989) : Rotational behaviour induced by theophylline in 6-OHDA nigrostriatal denerved rats in dependent on the supersensitivity of striatal dopamine receptors. Pharmacol. Biochem. Behav., 33, 609-613. 
Behavioral effects of methylxanthines

Daly, J. W., Butts-Lamb, P. and Padgett, W. (1983): Subclasses of adenosine receptors in the central nervous system : Interaction with caffeine and related methylxanthines. Cell. Mol. Neurobiol., 3, 69-80.

Dews, P. B. (1982): Caffeine. Ann. Rev. Nutr., 2, 323-341.

Fujii, W., Kuribara, H. and Tadokoro, S. (1989): Interaction between caffeine and methamphetamine by means of ambulatory activity in mice. Japan. J. Psychopharmacol., 11, 225-231.

Fredholm, B. B. (1980): Are methylxanthine effects due to antagonism of endogenous adenosine? Trends Pharmacol. Sci., 1, 129-132.

Fredholm, B. B., Herrera-Marschitz, M., Jonzon, B., et al. (1983): On the mechanism by which methylxanthines enhance apomorphine-induced rotation behavior in the rat. Pharmacol. Biochem. Behav., 19, 535-541.

Hagiwara, S. and Buerly, L. (1981): "Calcium channel". Ann. Rev. Neurosci., 4, 69-125.

Herrera-Marschitz, M., Casa, M. and Ungerstedt, U. (1988) : Caffeine produces contralateral rotation in rats with unilateral denervation: Comparison with apomorphine induced responses. Psychopharmacology (Berlin), 94, 38-45.

Holtzman, S. G. (1983): Complete, reversal and drug-specific tolerance to stimulation of locomotor activity by caffeine. Life Sci., 33, 779-787.

Katims, J.J., Annau, Z. and Snyder, S. H. (1983): Interactions in the behavioral effects of methylxanthines and adenosine derivatives. J. Pharmacol. Exp. Ther, 227, 167-173.

Kuribara, H. and Tadokoro, S. (1989) : Reverse tolerance to ambulation-increasing effect of methamphetamine and morphine in 6 mouse strains. Japan. J. Pharmacol., 49, 197-203.

Kuribara, H. and Tadokoro, S. (1989): Behavioral study on an antitussive and expectorant, and of its constituents I. Effects on ambulatory activity and discrete lever-press avoidance response in mice. Japan. J. Alcohol Drug Dependence, 24, 417-429 (Abs. in English).

Kuribara, H. and Tadokoro, S. (1992) : Behavioral effects of cocoa and its main active compound theobromine: Evaluation by ambulatory activity and discrete avoidance in mine. Japan. J. Alcohol Drug Dependence, 27, 168-179.

Logan, L., Carney, J. M., Holloway, F. A., et al. (1989) : Effects of caffeine, cocaine and their combination on fixed interval behavior in rats. Pharmacol. Biochem. Behav., 33, 99-104.

Lundberg, D. B., Breese, G. R. and Mueller, B. A. (1981): Aminophylline may stimulate respiration in rats by activation of dopaminergic receptors. $J$. Pharmacol. Exp. Ther., 217, 215-221.

Marangos, P.J. (1985) : Differential effects of caffeine on brain adenosine receptors and uptake site. In Adenosine : Receptors and Modulation of Cell Function (V. Stephanovich, K. Rudolphi and P. Schubert, eds.), p.191-198. IRL Press, Oxford. 


\section{H. KURIBARA et al.}

McKim, W. A. (1986): Drugs and Behavior: An Introduction to Behavioral Pharmacology. p.145-160. Prentice Hall, Englewood Criffs.

McMillen, B. A. (1983) : CNS stimulants: Two distinct mechanisms of action for amphetamine-like drugs. Trends Pharmacol. Sci., 4, 429-432.

Misra, A. L., Vadlamani, N. L. and Pontani, R. B. (1986) : Effects of cocaine on locomotor stimulant activity in rats. Pharmacol. Biochem. Behav., 24, 761-764.

Pentel, P. (1984) : Toxicity of over the counter stimulants. J. Am. Med. Assoc., 252, 1898-1903.

Schlemmer, R. F., Heinze, W. J., Aata, C. L., et al. (1984) : Caffeine potentiates phenylpropanylamine lethality but not motor behavior. Fed. Proc., 43, 572.

Seale, T. W., Johnson, P., Carney, J. M., et al. (1984) : Interstrain variation in acute toxic response to caffeine among inbred mice. Pharmacol. Biochem. Behav., 20, $567-573$.

Snyder, S. H., Katims, J.J., Annau, Z., et al. (1981): Adenosine receptors and behavioral actions of methylxanthines. Proc. Natl. Acad. Sci. USA, 78, 3260-3264.

Staahle, L., Segersvaerd, S. and Ungerstedt, U. (1990): Theophylline concentration in the extracellular space of the rat brain : Measurement by microdialysis and relation to behaviour. Eur. J. Pharmacol., 185, 187-193.

Watanabe, H., Ikeda, M. and Watanabe, K. (1981) : Properties of rotational behaviour produced by methylxanthine derivatives in mice with unilateral striatal 6-hydroxydopamine-induced lesions. J. Pharmacol.-Dynam., 4, 301-307. 